\title{
Universiteit
}

Leiden

The Netherlands

\section{Princely entries and gift exchange in the Burgundian Low Countries: a crucial link in late medieval political culture Damen, M.J.M.}

\section{Citation}

Damen, M. J. M. (2007). Princely entries and gift exchange in the Burgundian Low Countries: a crucial link in late medieval political culture. Journal Of Medieval History, 33, 233-249. Retrieved from https://hdl.handle.net/1887/14307

Version: $\quad$ Not Applicable (or Unknown)

License: $\quad$ Leiden University Non-exclusive license

Downloaded from: https://hdl.handle.net/1887/14307

Note: To cite this publication please use the final published version (if applicable). 


\title{
Princely entries and gift exchange in the Burgundian Low Countries: a crucial link in late medieval political culture
}

\author{
Mario Damen \\ Instituut voor Geschiedenis, University of Leiden, Postbus 9515, 2300 RA Leiden, The Netherlands
}

\begin{abstract}
This article treats the first entry of a new prince as the start of a series of exchanges between the prince and his subjects. On the occasion of an entry, gifts in all kind of forms, subsistence, luxury and symbolic goods, were exchanged with the intention of establishing a bond between the new ruler and the subjects. These gifts were not standardised in the Burgundian Low Countries. There was a wide range of gifts, from wine to silverware and from money to horses. Some gifts can be linked to the princely right of lodging in places he passed on his itinerary, whereas others refer to marks of honour offered by the host. However, not all gifts were given spontaneously, but were the result of a negotiating process between the town and the prince's officials on the one hand and between the different towns of a principality on the other. Those officials benefited as well from entry gifts that trickled down to lower levels in the official hierarchy. Therefore, the gifts can be considered as personalised items in a bigger process of exchange and as a confirmation of the outcome of political negotiations.
\end{abstract}

(c) 2007 Elsevier Ltd. All rights reserved.

Keywords: Gift exchange; Low Countries; Politics

\section{Introduction}

In 1549 the future Philip II of Spain made an inauguration tour through the Low Countries as the successor of his father Charles V. In his account of the prince's journey Calvete de Estrella describes how the prince was received by the town administrations. In Brussels, for example, the day after the

E-mail address: m.j.m.damen@let.leidenuniv.nl 
inauguration ceremony, the burgomasters, pensionaries and councillors of the town visited the prince in his palace on the Coudenberg. The first pensionary offered Philip on behalf of the town a preciously decorated cup of gold-plated silver. In a brief speech he told the prince that the citizens of Brussels had 'the strong desire to serve him as humble subjects and loyal vassals'. The prince gratefully accepted the gift and thanked them for their willingness to serve him. ${ }^{1}$ The gifts served as a confirmation of the oath of loyalty that prince and subjects had exchanged. However, it was not a generalised gift custom all over the Low Countries. The town administrations of Louvain, Binche and Antwerp also offered silverware. ${ }^{2}$ Malines offered a rich tapestry, the town's craft product par excellence. ${ }^{3}$ However, in his detailed description De Estrella does not mention anything of the kind in towns like Tournai, Lille, Bruges, Ghent, Dordrecht, Leiden, Haarlem and so on. Every town had its own 'gift policy' and decided with every entry if a gift was appropriate or not.

In this article I will treat the first entry of a new prince as the start of a series of exchanges between the prince and his subjects. I will argue that the relationship between prince and subjects was characterised by different forms of reciprocity. Gifts in all kind of forms, subsistencegoods, luxury goods and symbolic goods, were exchanged with the intention of establishing a bond between the new ruler and the subjects. Attention will be paid to both sides, thus avoiding a focus on one of the two parties involved or on the leading elements: the prince and the urban elites. Therefore, a part of this article is dedicated to the duke's retinue and household members who accompanied him during the entries. On the other hand, other groups in the town who participated in the entry as well as in the exchange will be observed. Finally, I will demonstrate how gift traditions at the court trickled down to urban milieus.

The 'Blijde inkomste' or joyous entry, the first entry of a new prince into a town, has long caught the historian's attention. Publications of, among others, Peter Arnade, Jesse Hurlbut, Hugo Soly and Hans Smit tended to focus on two central points: the theatrical and ritual parts of entry processions and the political function of the entries. ${ }^{4}$ More recently Elodie Lecuppre-Desjardin interpreted the entries as a form of symbolic communication between the prince and his subjects, with the goal of legitimising the power of the new duke. ${ }^{5}$ Blockmans and Prevenier integrated both artistic patronage and the organisation of mass spectacles such as joyous entries into the concept of the Burgundian theatre state. The main point was that the loyalty of the subjects was stimulated by this kind of ceremony that aimed to impress the public with pomp and spectacle. ${ }^{6}$ Bernard Guenée

\footnotetext{
${ }^{1}$ Juan Cristóbal Calvete de Estrella, El felicissimo viaie d'el mvy alto y mvy poderoso Príncipe Don Phelippe, hijo d'el Emperador Don Carlos Quinto Maximo, desde España à sus tierras dela baxa Alemaña. Con la descripcion de todos los Estados de Brabante y Flandes (Antwerp, 1552), f. 68r-v.

${ }^{2}$ In Louvain and Binche a gold-plated silver cup and in Antwerp two big silver flasks. Calvete de Estrella, El felicissimo viaie, f. $88 \mathrm{v}, 212 \mathrm{v}, 260 \mathrm{r}$.

${ }^{3}$ Calvete de Estrella, El felicissimo viaie, f. $219 \mathrm{v}$.

${ }^{4}$ Literature on joyous entries is abundant. I only mention here the books and articles that are relevant for this article. Peter Arnade, Realms of ritual. Burgundian ceremony and civic life in late medieval Ghent (New York, 1996); Jesse D. Hurlbut, 'The duke's first entry: Burgundian inauguration and gift', in: Moving subjects: processional performance in the middle ages and the renaissance, ed. Kathleen Ashley and Wim Hüsken (Amsterdam, 2001), 155-87; Gordon Kipling, Enter the king. Theatre, liturgy, and ritual in the medieval civic triumph (Oxford, 1998); Hugo Soly, 'Plechtige intochten in de steden van de Zuidelijke Nederlanden tijdens de overgang van middeleeuwen naar nieuwe tijd: communicatie, propaganda, spektakel', Tijdschrift voor geschiedenis, 97 (1984), 341-61.

${ }^{5}$ Elodie Lecuppre-Desjardin, La ville des cérémonies. Essai sur la communication politique dans les anciens Pays-Bas bourguignons (Turnhout, 2004), 151-2.

${ }^{6}$ Wim Blockmans and Walter Prevenier, The promised lands. The Low Countries under Burgundian rule, 1369-1530 (Philadelphia, 1999), 140.
} 
even maintained for the French royal entries that they became in the late middle ages one of the most important moments in the 'religion royale'.

Andrew Brown and David Nicholas have criticised the concept of the Burgundian theatre state. They are of the opinion that the theatre state approach is too top down orientated. The dukes did not invent ceremonies and rituals to impress their citizens; the cities themselves had a rich tradition of organising all kinds of processions and ceremonies and the dukes engaged with these. As Brown puts it: 'Their ceremonies had the power to move because they could be interpreted as local - rather than because they were "splendid". 8 On the other hand, the spectacles in the Flemish and Brabantine towns were too easily projected on other principalities of the Burgundian Low Countries. Hans Smit demonstrated that the entry as a mass spectacle with decorations, coats of arms, tableaux vivants and triumphal arches, were typical only for the big commercial or administrative urban centres as Bruges, Ghent, Brussels and Malines. In the much smaller towns of Holland, however, Smit could not detect these elements, even in their most rudimentary form, until the beginning of the sixteenth century. On average towns like Dordrecht, Leiden, Haarlem and Amsterdam spent no more than two percent of their yearly budget on entries. ${ }^{9}$ The city not only had to lodge and feed the king's household but also had to buy expensive presents. These presents normally made up at least $50 \%$ of the total costs of an entry. ${ }^{10}$

Besides the theatrical and ritual aspect, the political function of the entries has not remained unnoticed and is much less debated. The central element of the entry is the exchange of oaths. Both the prince and the subjects agreed in a kind of government contract. According to Arnade 'the entry served as a vehicle, rooted in the notion of a legal contract, through which both ruler and townspeople publicly confirmed their privileges and duties with an exchange of rights'. ${ }^{11}$ The ritual of homage had feudal roots and consisted of 'a mutual promise of protection on one hand and fidelity and support on the other'. ${ }^{12}$ Following this line of argument, Gordon Kipling maintained that the first offering of a gift to a new prince constitutes a primal act of homage by the subjects. The gift symbolises 'the feudal devotion which the subjects offered to their rightful sovereign'. The description of Calvete de Estrella of the gift ceremony in Brussels, confirms this idea. Kipling compares this gift giving with that of the three magi to the newly-born Jesus who by doing so recognised him as the messiah, the king of kings. ${ }^{13}$ But stress on the symbolic meaning of the gifts and interpreting the gift giving as an act of recognition, would underplay the importance of the act as the start of a cycle of reciprocity in which the relationship between prince and subjects is continuously being affirmed and reinforced by mutual visits and mutual presents.

\footnotetext{
${ }^{7}$ Bernard Guenée and Francoise Lehoux, Les Entrées royales francaises de 1328 à 1515 (Paris, 1968), 18.

${ }^{8}$ David Nicholas, 'In the pit of the Burgundian theater state. Urban traditions and princely ambitions in Ghent, 1360-1420', in: City and spectacle in medieval Europe, ed. Barbara A. Hanawalt and Kathryn L. Reyerson (Minneapolis, 1994), 271-95; Andrew Brown, 'Ritual and state-building: ceremonies in late medieval Bruges', in: Symbolic communication in the late medieval town, ed. J. van Leeuwen (Louvain, 2006) in press.

9 J.G. Smit, Vorst en onderdaan. Studies over Holland en Zeeland in de late middeleeuwen (Louvain, 1995), 345-7, 404-5.

${ }^{10}$ Guenée and Lehoux, Les Entrées royales, 9-10.

11 Arnade, Realms of ritual, 129.

${ }^{12}$ Wim Blockmans and Esther Donkers, 'Self-representation of court and city in Flanders and Brabant in the fifteenth and early sixteenth centuries', in: Showing status. Representation of social positions in the late middle ages, ed. Wim Blockmans and Antheun Janse (Turnhout, 1999), 85.

${ }^{13}$ Kipling, Enter the king, 116-8, 130-2.
} 


\section{Inauguration gifts}

The concern for honour and reputation was predominant in the middle ages and not restricted to noble and princely environments. Town administrations more than aristocrats had to do their best in building up a reputation or keeping up the honour of the town. ${ }^{14}$ When important guests visited a town it was therefore important to give them a proper welcome. This welcome included several gifts. Actually, it was a form of good neighbourship that was intended to strengthen external relationships and to promote the image of the generous town. As the committee that prepared the reception of King Louis XI in Tournai in 1464 expressed it: 'adfin que ledit seigneur perchoive la bonne voulenté et affection que les habitans de ladite ville, ses loyaux subjects, ont envers lui'. ${ }^{15}$ The town wanted to make a good impression on the new prince by showing its hospitality. This was expressed by gift giving which became an essential part of the visit of high-ranking guests'. ${ }^{16}$

The first visit of the prince was in itself considered as a gift. This becomes clear when the words of welcome by the town administrations are examined. Time and again it is stated that the presence of the prince is highly valued. ${ }^{17}$ Indeed, in the Burgundian and Habsburg periods, the joyous entry became one of the few occasions on which the subjects could meet and see their prince, at least in the northern principalities. The town rewarded the visit of the prince by offering him hospitality, public space, spectacle and gifts.

The hospitality offered by the town was expressed in several ways. A delegation of the town administration waited for the prince outside the town to welcome him. Sometimes they offered the prince the keys of the town, symbolising the grant of the city as a whole. ${ }^{18}$ With these keys he could not only open the gates, but also enter the main roads and squares and the city hall. The prince could use the town's public space to show himself to his subjects in all his glory. The entry of Charles the Bold into Ghent on 28 June 1467 demonstrates that the town literally had to hand over the public space. The day of Charles's entry coincided with one of Ghent's most popular religious processions, that of St Lieven. ${ }^{19}$ The St Lieven pilgrims did not accept that the duke should occupy the public space that was destined for their festivity and rioted against him and the town's aldermen who had arranged the entry without consulting them.

When the prince stayed overnight, the town usually paid the costs of food and lodging. He could stay in one of his own residences, for example the Prinsenhof in Bruges or the Coudenberg in Brussels, in one of his houses that were maintained as princely inns, for example, in Leiden the house Lockhorst next to the church of St Pieter where Charles V stayed in 1515 , or in an ecclesiastical institution as for example the convent of the knights hospitaller in Haarlem. ${ }^{20}$ A common characteristic of these residences is that the town contributed financially in one way or another to the maintenance of the buildings and the salary of the innkeepers.

The prince retired to his residence after the oath ceremony had taken place. At the end of the day, usually after dinner, or, when it was too late, the day after the oath ceremony, a delegation

\footnotetext{
${ }^{14}$ Felicity Heal, Hospitality in early modern England (Oxford, 1990), 302.

15 Guenée and Lehoux, Les Entrées royales, 184.

${ }^{16}$ Heal, Hospitality, 302-3.

${ }^{17}$ Smit, Vorst en onderdaan, 561-3.

18 Kipling, Enter the King, 118.

19 Arnade, Realms of ritual, 145.

${ }^{20}$ Smit, Vorst en onderdaan, 80, 84.
} 
of the town administration came to offer the prince the inauguration gifts. ${ }^{21}$ It is important that the gifts were handed over not during the welcome of the prince outside the city's gates but only after the oath ceremony had taken place. The gifts of the town represented in this way the confirmation of the political bond established by the oaths. The interval of time between the arrival of the prince and the gift of the town is crucial. As Bourdieu indicated the interval had the function of creating a screen between the gift and the counter gift and allowing two perfectly symmetrical acts to appear as unique and unrelated acts'. ${ }^{22}$

\section{Wine and silverware}

Gifts for the prince on the occasion of his joyous entry were not standardised in the Low Countries. Every town donated something different although sometimes a neighbouring town was consulted on the gift to be given; of course one could not give less than one's neighbour although a relatively bigger gift was considered overdone. Moreover, the presents differed over time although it was frequently stated that a present was given 'according to the old custom'. As Valentin Groebner noticed for Basel, 'presents constantly needed to be adapted to new conditions'. ${ }^{23}$ Table 1 shows the gifts of some towns to Charles V in 1515. Distinction has to be made between consumable and luxury goods. Gerrit Jasper Schenk, who wrote a book on late medieval princely entries in the Holy Roman Empire, labelled these quite accurately as 'Gastung' and 'Ehrung'. ${ }^{24}$ Whereas the first category of gifts can be linked to the princely right of lodging in places he passed on his itinerary, the second category refers to marks of honour offered by the host.

Until the first entry of Charles the Bold in 1468, most entry gifts for the count of Holland, were restricted to 'Gastung', consumable goods, mainly wine. Wine gifts to visitors can already be detected in the 'libatio', the joint ritual drinking in Merovingian and Carolingian times. Drinking rituals were occasions for strengthening social relationships within the warrior societies of these times. In the late middle ages the custom became institutionalised in the cities. ${ }^{25}$ For Holland, urban wine gifts for the prince can be traced back to 1266 when in the first charter granted to Leiden Floris V stipulated that the count should receive a barrel of wine on the occasion of the confirmation of its privileges. ${ }^{26}$ Wine had (and still has) a higher status than beer and that is why that even in these beer producing cities wine was the most appropriate liquid to use within political relationships.

As Table 1 shows, Leiden and Haarlem donated both three aam, which is 465 litres, to the prince in 1515. Louvain, Den Bosch and Bruges also offered relatively large quantities of probably white Rhine wine. Mons in Hainault distinguished itself by offering a very fine selection of

\footnotetext{
${ }^{21}$ Smit, Vorst en onderdaan, 331. Tournai: Guenée and Lehoux, Les Entrées royales, 188. German empire: Gerrit Jasper Schenk, Zeremoniell und Politik. Herrschereinzüge im spätmittelalterlichen Reich (Cologne, 2003), 392.

22 Pierre Bourdieu, Practical reason (Stanford, 1998), 94.

${ }^{23}$ Valentin Groebner, Liquid assets, dangerous gifts. Presents and politics at the end of the middle ages (Philadelphia, 2002), 28.

${ }^{24}$ Schenk, Zeremoniell und Politik, 392.

25 Jan Dhondt, Das frühe mittelalter (Frankfurt am Main, 1968), 118-20. Alain Derville, 'Les pots-de-vin dans le dernier tiers du XVe siècle (d'après les comptes de Lille et de Saint-Omer)', in: 1477. Het algemene en de gewestelijke privilegiën van Maria van Bourgondië voor de Nederlanden, ed. W.P. Blockmans (Kortrijk-Heule, 1985$), 451$.

${ }^{26}$ Smit, Vorst en onderdaan, 334; Oorkondenboek van Holland en Zeeland tot 1299. Deel: III: 1256 tot 1278, ed. J.G. Kruisheer (Assen, 1992), 468 article 20.
} 
Table 1

Gifts of the towns to Charles V on the occasion of his inauguration in $1515^{1}$

\begin{tabular}{|c|c|c|c|}
\hline & Silverware & Wine & Other \\
\hline Louvain & 3 jugs & 1 stic & 4 black Louvain cloths \\
\hline Den Bosch & 2 jugs, 1 cup & 2 voeder & \\
\hline Bruges & & 1 stic & $100 \mathrm{lb}$. gr. \\
\hline Mons & $\begin{array}{l}1 \text { cup filled with } 200 \\
\text { golden Philippus guilders }\end{array}$ & 3 queus & \\
\hline Leiden & & $3 \mathrm{aam}$ & $\begin{array}{l}\text { Repayment of leased } \\
\text { princely rights and domains }\end{array}$ \\
\hline Haarlem & & 3 aam & two stallions \\
\hline Middelburg & 1 big cup & & \\
\hline
\end{tabular}

\begin{abstract}
${ }^{1}$ Sources: Collection des voyages des souverains des Pays-Bas. T. II: Itineraire de Charles-Quint de 1506 a 1531. Journal des voyages de Charles-Quint, de 1514 a 1551 par Jean de Vandenesse ed. L.P. Gachard (Brussels, 1874) (hereafter Gachard II), 519-58; Inventaris der archieven van de stad 's Hertogenbosch I, 300-302; H.M. Kesteloo, 'De stadsrekeningen van Middelburg', Archief Zeeuwsch Genootschap 6 (1888), 332, 400; Smit, Vorst en onderdaan, 333-9; Haarlem, Archiefdienst Kennemerland, Stadsarchief Haarlem (hereafter AKH, SAH) 397 f. 87r-89v (I thank Arie van Steensel for the transcriptions of these pages); Leiden, Regionaal Archief, Secretarie-archief I (hereafter RAL, SA I) 594 f. $77 \mathrm{v}-83 \mathrm{r}$.
\end{abstract}

red French wine. Both wines were comparable in price and appreciation - second only to the higher evaluated Mediterranean wines - and the offerings in these towns corresponded with trade routes of which they formed part. ${ }^{27}$ The quantities given seem overwhelming but were in reality relatively modest taking into consideration that Charles's retinue numbered of more than two hundred men, and that the wine was probably distributed among the members of his household and consumed in situ. Other current consumable entry gifts such as fish and oxen were not given in 1515 . Oats, a common gift to princes during their first entry into the Holy Roman Empire, were not very often given in the Low Countries. It can therefore not be a coincidence that the only evidence of a gift of oats is to Emperor Maximilian in 1508 by Den Bosch. ${ }^{28}$

There was more variety in the luxury goods that were offered. Louvain offered black cloth, Bruges money and Haarlem two stallions. A horse was a typical gift that functioned in gift exchange between nobles. In 1497, for example, the lords of IJsselstein, Egmond, Brederode and Montfoort, that is the top layer of the nobility of Holland, all offered a horse to Philip the Fair during his entry. ${ }^{29}$ In general, gift-exchange between western European rulers and their courtiers was closely connected with horses. In particular luxury horses were appreciated as gifts

\footnotetext{
${ }^{27}$ R. van Uytven, “'Wijn es goet dranck...”. Het middeleeuwse wijndiscours', in: R. Van Uytven, De zinnelijke Middeleeuwen (Louvain, 1998), 31-3.

${ }^{28}$ Inventaris der archieven van de stad 's Hertogenbosch, chronologisch opgemaakt en de voornaamste gebeurtenissen bevattende I (Stadsrekeningen van het jaar 1399-1800), ed. R.A. van Zuijlen Jr ('s Hertogenbosch, 1863), 159; Kroniek van Peter van Os. Geschiedenis van 's-Hertogenbosch en Brabant van Adam tot 1523, ed. A.M. van Lith-Droogleever Fortuijn, J.G.M. Sanders, G.A.M. Van Synghel (The Hague, 1997), 310.

${ }^{29}$ Lille, Archives Départementales du Nord, Serie B, Chambre des Comptes (hereafter ADN B) 2148 f. 161r; ADN B 2159 f. 193v, 195r, 196v. The horses were presented on June 23 (IJselstein and Egmond in The Hague), June 26 (Brederode in Amsterdam) and July 19 (Montfoort in Gouda). The lord of IJsselstein even presented a second horse ('encores ung cheval') to Philip on July 15. See on Philip's itinerary Smit, Vorst en onderdaan, 243-4.
} 
at medieval courts and were given to military captains as a reward for participating in military campaigns. $^{30}$

Den Bosch, Louvain, Mons and Middelburg all offered silverware, albeit in a different form. This valuable gift represented on the one hand the generosity and prosperity of the town. On the other hand it was a sign of the incipient relationship between the new prince and the town. ${ }^{31}$ The type of silverware that was given was nearly always connected with drinking. Normally, the coats of arms of the town were engraved on the silver jugs, pitchers and cups, in order to remind the recipient of the giver. In this sense the gifts functioned as an important element of urban self-representation. ${ }^{32}$ In Mons the silver cup was even filled with golden coins, a common practice at the end of the middle ages. The importance of ritual drinking comes again to the fore: next to the offering of real liquid ('Gastung'), the honorary gift was presented as a liquid as well. ${ }^{33}$

Gifts of silverware show that these were not given automatically or out of a sense of tradition. The town administration of Leiden, for example, presented in 1497 for the first time two silver jugs to Philip the Fair. In contrast in 1508 it gave two horses to Maximilian whereas in 1515 the gift to Charles consisted of a repayment of leased princely rights and domains. ${ }^{34}$ Considering the difficult financial situation of the town in these years, it is clear that the availability of cash was not decisive nor what kind of present was given. As we have already seen, the entry gifts in 1549 diverged markedly. Whereas the major Brabantine towns donated silverware, the towns of Holland and Flanders apart from spectacles did not offer anything, as far as we know. Probably they thought that the financial contributions, the 'servicios', were more than sufficient and did not attach great value to a symbolic gift of silverware. The town decided for every entry what was appropriate for the new prince.

Gifts of silverware were typical for princely hospitality in western Europe. Visiting ambassadors were traditionally given the cups they had used during their stay at the court. In the late middle ages these cups or flagons were the usual gifts to ambassadors. ${ }^{35}$ However, increasingly the value of the silverware was given in cash in order that the ambassadors could support themselves according to their estate and, more important, that they could pay for their journey back. ${ }^{36}$ Thus, the towns of the Low Countries picked up a princely gift tradition in the late middle ages that was almost abandoned by the princes themselves. Gifts of silverware can be characterised as personalised items in a bigger process of exchange of which the negotiations on new 'aides' or subsidies were the most important.

In 1515 Bruges offered next to a money gift of a $100 \mathrm{lb}$. gr., a spectacle of eleven tableaux vivants which showed the new prince a clear message: the town had known times of great prosperity but was facing now an unmistakable decline. With this propagandistic gift to the prince, the town hoped for drastic measures to recover economic growth. This petition for help came

\footnotetext{
${ }^{30}$ Bertrand Schnerb, 'Le cheval et les chevaux dans les armées des ducs de Bourgogne au XIVe siècle', in: Commerce, finances et société (XI ${ }^{e}-X V I^{e}$ siècles). Recueil de travaux d' histoire médiévale offert à M. le professeur Henri Dubois, ed. Philippe Contamine a.o. (Paris, 1993), 82-3.

${ }^{31}$ Lecuppre-Desjardin, La ville, 126.

${ }^{32}$ Groebner, Liquid assets, 32.

33 Groebner, Liquid assets, 64.

${ }^{34}$ Smit, Vorst en onderdaan, 334-6; RAL, SA I 382 d.d. 3-7-1497.

${ }^{35}$ Petra Ehm, Burgund und das Reich. Spätmittelalterliche Aussenpolitik am Beispiel der Regierung Karls des Kuhnen (Munich, 2002), 278.

${ }^{36}$ Ehm, Burgund, 278.
} 
from the notion of the social contract that the ruler had with his citizens, not from his position as an autocratic prince. ${ }^{37}$ Thus, material gifts were sometimes only a supplement for a political message that the town wanted to communicate to its ruler.

\section{Subsidies: taxes or gifts?}

The data from Table 1 show that money was not a regular entry gift in 1515 . However, one has to consider that money gifts were sometimes disguised as other types of payments, subsidies for example. Traditionally, a prince in the Low Countries could demand a subsidy of his citizens for a specific reason, for example when he was knighted, on the occasion of his wedding and for the payment of a ransom. However, every principality had its own tradition in this respect, and within a principality differences existed between the privileges of the towns. ${ }^{38}$ The tradition of a subsidy on the occasion of the prince's inauguration existed in the counties of Flanders, Artois and Zeeland and in the duchy of Brabant. But all depended on specific political circumstances.

In Flanders for example, Philip the Bold and Mary of Burgundy did not receive a subsidy on their accession to comital power. John the Fearless and Philip the Good were even refused a subsidy on their inauguration, although they pretended it to be a custom. Philip the Good for example asked for it 'as a new prince and count of Flanders, to whom as to his forefathers one was obliged to give a courtesy and a subvention'. ${ }^{39}$ The terminology used, 'hoofschede ende subvencie', however, is revealing. The subsidy is still perceived as a courtesy, as a gift. ${ }^{40}$ Significantly, the request was not complied with by the Members and Estates of Flanders.

In Holland this tradition, invented or not by the prince, did not exist. In 1389 the towns and communities of Holland conceded Albert of Bavaria a subsidy, not collectively but individually, on his inauguration tour. The representatives stated explicitly that the subsidy was conceded as 'a favour and not by right'. ${ }^{41}$ However, some of his successors as counts of Holland used the argument of the inauguration for the petition of new subsidies. Charles the Bold, who asked for several new subsidies, even maintained that he had spared his subjects because he did not ask

\footnotetext{
${ }^{37}$ There is abundant literature on this entry. See for further references Soly, 'Plechtige intochten', 346-7; Blockmans and Donkers, 'Self-representation', 108-10; P. Burke, 'Karel V (her)bekeken', in: Karel V, 1500-1558', ed. H. Soly (Antwerpen, 1999), 441.

${ }^{38}$ Robert Stein, table 1 in his chapter on the subsidies in his forthcoming book on Burgundian stateformation.

${ }^{39}$ Handelingen van de Leden en van de Staten van Vlaanderen (1419-1467) I, ed. W.P. Blockmans (Brussels, 1990), no. 6. For an overview of al the subsidies demanded and conceded in Flanders, W.P. Blockmans, De volksvertegenwoordiging in Vlaanderen in de overgang van Middeleeuwen naar Nieuwe Tijden (1384-1506) (Brussels, 1978), 610-21 (table 9). See also A. Zoete, De beden in het graafschap Vlaanderen onder de hertogen Jan Zonder Vrees en Filips de Goede (1405-1467) (Brussels, 1994), 40.

40 See on 'hoofscheden': Norbert Elias, Het civilisatieproces: sociogenetische en psychogenetische onderzoekingen (Utrecht, 1982), 91; W.P. Gerritsen, 'Wat is hoofsheid? Contouren van een middeleeuws cultuurverschijnsel,' in: Hoofse cultuur. Studies over een aspect van de middeleeuwse cultuur, ed. R.E.V. Stuip and C. Vellekoop (Utrecht, 1983), 26-30, 39-40; Mario Damen, 'Corrupt of hoofs gedrag? Geschenken en het politieke netwerk van een laat-middeleeuwse Hollandse stad', Tijdschrift voor sociale en economische geschiedenis, 2 (2005), 68-94.

${ }^{41}$ Bronnen voor de geschiedenis der dagvaarten van de staten en steden van Holland voor 1544. I: 1276-1433, tweede stuk: Teksten, ed. W. Prevenier and J.G. Smit (The Hague, 1987), nos 481, 482; J.A.M.Y. Bos-Rops 'Van incidentele gunst tot jaarlijkse belasting: de bede in het vijftiende-eeuwse Holland' in Fiscaliteit in Nederland. 50 jaar Belastingmuseum "Prof.Dr. van der Poell”, ed. J.Th. de Smidt a.o. (Zutphen and Deventer, 1987), 22.
} 
for a subsidy for his inauguration. ${ }^{42}$ In 1477 , after his death, the situation is very clear: Mary and Maximilian linked their request for new subsidies with the attacks of King Louis of France. They considered the subsidies as a continuation of the subsidies granted to Charles the Bold and not as a new subsidy for their inauguration. ${ }^{43}$ In 1494, however, Philip the Fair asked the Estates of Holland for a subsidy because of his inauguration. ${ }^{44}$ Although the Estates consented to the inauguration taking place in a central place, instead of an inauguration tour, they did not directly give in to the wish for new taxes and continued to negotiate on the subject.

To summarise, the subsidy for the inauguration developed from a one-time present to a regular subsidy for which the reasons got mixed up. This becomes very clear in the Habsburg period when the subsidies were less and less considered as a voluntary allowance of the subjects but as impositions continued by the prince for the needs of his administration. ${ }^{45}$ At this point money as a gift at the inauguration could make its comeback. When Philip of Spain in 1549 was welcomed as successor to his father Charles V, his deputies explicitly asked the Estates of the different principalities for a gift of money, 'servicio', to be handed over in cash after the inauguration ceremony. The Estates of Holland donated 50,000 guilders - 10,000 less than the requested 60,000 - and the cities did not offer any other gifts, except for some meals. Brabant, however, offered twice as much whereas Flanders donated 120,000 guilders. ${ }^{46}$ Although in France this 'joyous accession gift' was already common at the end of the fifteenth century, ${ }^{47}$ in the Low Countries it was a new phenomenon. Therefore, this type of gift should not be interpreted as a voluntary act of generosity but as the outcome of political negotiations.

\section{Gifts for the retinue}

In this section the focus shifts from the prince to his retinue. Although the retinue, consisting of close relatives, court and state officials, could number up to more than 200 people, they are hardly ever mentioned in the narrative sources. However, all these men had to be housed and it was impossible to lodge them all in the princely residence. Therefore, house owners had to open their doors for the prince's retinue. A list of the most appropriate houses was made in advance, sometimes in collaboration with the prince's quartermaster. Every member of the retinue was housed in accordance with his rank and status. ${ }^{48}$ In Tournai in 1464 the guards of Louis XI had to be housed as close as possible to the king's hostel because of safety reasons. In the same town someone who refused to put his house at the prince's retinue disposal, was considered a rebel. ${ }^{49}$ In Amsterdam during the entry of Philip the Fair in 1497 those who refused would be corrected in 'lijff ende goet' that is in person and property. They had to be punished to save the honour of the prince. ${ }^{50}$

\footnotetext{
42 Vaughan, Charles the Bold, 400-1.

${ }^{43}$ RAL, SA I 556, f. 74r-v.

${ }^{44}$ RAL, SA I 382, f. 407v and Smit, Vorst en onderdaan, 239-40.

${ }^{45}$ Natalie Zemon Davis, The gift in sixteenth century France (Oxford, 2000), 158.

${ }^{46}$ Smit, Vorst en onderdaan, 252, 334. Calvete de Estrella gives slightly different figures but the proportions are the same: f. 181v, 267r, 289v.

${ }^{47}$ Davis, The gift, 158.

48 '(...) omme die heren, dienaeren ende familien van onsen genadichsten heere eerlijcke, chierlijcke ende vrientlijcke te ontfangen ende logieren, elck nae sijn staet, condicie ende toebehoren': Smit, Vorst en onderdaan, 541.

49 'Et que nul ne mefface aux gens et officiers du roy, sur estre pugnis': Guenée and Lehoux, Les Entrées royales, 189.

${ }^{50}$ Smit, Vorst en onderdaan, 541: als nae die sake van hoere misbruyck tot eer van onsen genadichsten heere behoren sall gedaen te wesen.
} 
Of course hospitality was not the only thing the city had to offer to the retinue. The tradition of entry gifts for a new prince trickled down to lower levels in the official hierarchy. Bruges offered the new chancellor Nicolas Rolin in 1423/24 12 silver plates because of his 'eersten incommene als canchellier', that is because of his first entry as chancellor. ${ }^{51}$ However, in Holland this tradition was unknown until the end of the fifteenth century. In July 1497 both the recently appointed chancellor Thomas de Plaine and the first chamberlain Cornelis van Bergen, asked the Leiden administration for a gratuity just like the prince used to receive during his first entry. Two weeks before Philip the Fair had made his first entry into the town and probably the highest officers of his state and court apparatus had made their request during this event. Nevertheless, the town administration wanted to investigate if it was a custom and if other towns would give a similar gift. Apparently, the custom did not exist, although three years before the Estates of Holland had given a gratuity to De Plaine on the occasion of his first entry as president of the Grand Council. ${ }^{52}$ Because the other major towns of Holland did not give anything Leiden finally decided not to submit under the pressure of the officers. ${ }^{53}$ Again, we see a divergence of gift traditions in the towns of the Low Countries. Probably, in Flanders the tradition of a gift to the chancellor was more rooted as the county together with the duchy of Burgundy belonged to his original jurisdiction.

Town administrations were fully aware that the joyous entry was the right moment to win the favour of the prince's favourites. The preparations for the entry of Louis XI in Tournai demonstrate this. The town administration was aware that the entry had to be used to 'acquerir moyens et amis, samble que a aucuns especiaulx seigneurs appartiendroit faire aucuns honnestes et gracieulx presens, affin que tousjours ... ilz eussent la ville pour recommandee' ${ }^{54}$ The hope for reciprocity is explicitly stated here. Gifts were not only destined for the prince but also for some 'special lords' to be sure that they would act positively in the future for the benefit of the town.

What kind of gifts then were given to these 'seigneurs', to the top echelons of the prince's household? Table 2 gives an overview of the gifts several members of Charles V's retinue received during his entry into various towns of the Low Countries. Notice that in 1515 both Haarlem and Middelburg rewarded the chancellor and the first and second chamberlain with money gifts of 50 pounds. This money was given as the town's accounts note, in appreciation of certain favours done for the town's benefit. ${ }^{55}$ Bruges also bestowed on the chancellor and the stadholder of the district of Lille, Douai and Orchies a substantial amount of money.

As indicated above entries were appropriate occasions to negotiate on new taxes in exchange for new privileges. The contacts between princely officers and the political elite of the town intensified because of these negotiations and the preparations of the entries. Shortly after the entry of Philip the Fair in 1497, Leiden donated gratuities ('gratuyteyten') among others to

\footnotetext{
${ }^{51}$ L. Gilliodts-van Severen, Inventaire des archives de la ville de Bruges. Section première: inventaire des chartes XIIIe au XVIe siècle I (Bruges, 1871), 430.

52 The Hague, Nationaal Archief, Staten van Holland, 1715 f. 17r.

${ }^{53}$ RAL, SA I 382 f. 466r-467v. (I thank dr. Marjan Vrolijk and dr. Hans Smit of the Instituut voor Nederlandse Geschiedenis for this reference). See also Smit,Vorst en onderdaan, 340. Their biographies in Hans Cools, Mannen met macht. Edellieden en de moderne staat in de Bourgondisch-Habsburgse landen (1475-1530) (Zutphen, 2001), 215-17, 278-9.

54 Guenée and Lehoux, Les Entrées royales, 189-90.

$55 \mathrm{AKH}, \mathrm{SAH}, 397$ f. 87v: 'tot een dancbairheyt van sekere deuchden ende vrientscepen die zij luyden der voirs. stede in diversche hueren saicken gedaen hebben ende in gods wille noch meer doen sullen'.
} 
Table 2

Selection of gifts from the towns to the retinue (high-ranking) of Charles V on the occasion of his inauguration in $1515^{1}$

\begin{tabular}{|c|c|c|c|c|c|c|c|c|}
\hline Name & Function & Louvain & Den Bosch & Bruges & Mons & Leiden & Haarlem & Middelburg \\
\hline Margaret of Austria & Regent & 1 stuck wine & 3 aam wine & & wine & & $1 \mathrm{aam}$ & \\
\hline Eleanor & Sister Charles V & & & & silver cup + wine & & & \\
\hline Guillaume de Croy & First chamberlain & & 1 aam wine & & silver pot & 8 jugs & $\begin{array}{l}8 \text { jugs } \\
50 \mathrm{lb} .\end{array}$ & $50 \mathrm{lb}$ \\
\hline Jean Sauvage & Chancellor of Burgundy & & 12 jugs & 200 philippus guilders & Wine & 6 jugs & $\begin{array}{l}8 \text { jugs } \\
50 \mathrm{lb} .\end{array}$ & $50 \mathrm{lb}$. \\
\hline Anthony of Lalaing & Second chamberlain & & & & & 6 jugs & $\begin{array}{l}8 \text { jugs } \\
50 \mathrm{lb} .\end{array}$ & $50 \mathrm{lb}$. \\
\hline \multirow[t]{2}{*}{ Jacques de Luxembourg } & Stadholder Flanders Gallicant & & & 800 philippus guilders & & & & \\
\hline & President of Burgundy & 3 pitchers & & & & 4 jugs & & \\
\hline Floris van Egmond & Stadholder Holland-Zeeland & 8 pitchers & & & & 6 jugs & & \\
\hline Philip of Cleves & & & 8 jugs & & & 8 jugs & & \\
\hline Ferry de Croy & Steward & & 8 jugs & & & 6 jugs & 8 jugs & \\
\hline
\end{tabular}

${ }^{1}$ Sources: see footnote in Table 1. 
chancellor Thomas de Plaine, his wife and son because of a privilege on the payment of 'renten' (annuities). Whereas De Plaine at the same time was refused a gift because of his first entry as chancellor, these gratuities were given for concrete services performed. ${ }^{56}$ Still, the chancellor's wife and son would not have done very much in this administrative matter. The same happened in 1464 when Tournai spent less money on the entry gift for the chancellor than on the silverwork given to his wife. ${ }^{57}$ One could say that these towns had a clear vision how politics work: the most important political decisions are made in the bedroom where the powerful present their problems to their wives. What is more, by rewarding gifts on family members, the towns could influence the attitude of the office-holders themselves.

Mons was the only town that offered silverware: a cup to Charles's sister Eleanor and a 'pot' to first chamberlain Guillaume de Croy 'in order that he would have the town and its citizens in good recommendation'. Both cups had an engraving of a 'léoncheau' (a small lion) carrying the arms of the town. ${ }^{58}$ This would remind the beneficiaries of the generosity of the town. Thus, these gifts had a clear intention of eliciting a counter gift. Again the expectation of reciprocity is explicitly mentioned in the sources. Of course the first chamberlain himself would never read the town's account so it was to remind the town administration of the services that could be expected to follow.

Table 2 demonstrates that the towns mainly donated wine, a common practice all over Europe. A wine gift was a token of respect for a visitor and served as a sign of recognition of the services he had rendered in the past or would render in the future for the benefit of the town. Every officer received a quantity of wine in accordance with his place in the official hierarchy. Still, the towns estimated some officers differently. First chamberlain Guillaume de Croy, for example, received in Den Bosch as much wine as the regent Margaret of Austria received, one aam of wine. Haarlem also donated one aam to Margaret but gave only 8 jugs to the first chamberlain, as Leiden did. The chancellor Jean le Sauvage received in Den Bosch 12 jugs, in Haarlem 8 jugs and in Leiden 6 jugs. So a fixed wine hierarchy did not exist. Every town decided what to give to every individual officer, although the internal hierarchy of the court and state apparatus was more or less respected. Furthermore, from the table it can be deduced that the top officials who accompanied the new prince changed with every entry. Even in the week between the visit to Haarlem and Leiden the composition of the retinue changed.

In Haarlem at least 185 officers received more than 1200 litres of wine. More than half of this quantity was given to 21 high-ranking officers who of course had to distribute their wine among their own retinue. The distribution of wine to several hundreds of officers was a complicated matter and mistakes were easily made as the retinue was too big to come together in one central inn or even in the city hall. Therefore the town administration distributed lead tokens, every symbol worth half a jug, which is almost 2.5 litres, with which all officers could obtain their wine gift in one of the town's inns. ${ }^{59}$

\footnotetext{
${ }^{56}$ RAL, SA I, 577 f. 96r.

${ }^{57}$ Guenée and Lehoux, Les Entrées royales, 198-9. The chancellor's wife received the gift 'en consideration de pluiseurs plaisirs et admistiés que mon dit seigneur le chancellier a par cy devant fais a icelle ville et aussy que tousjours icelle ville et ses drois et privileges lui pleust avoir en sa grace et recommendation'.

58 Gachard II, 544.

59 ( (...) van 500 loden teyckenen die hij bij beveele van den burgermeesteren in een vorme geghoten heeft ende die gedistribueert worden den heeren ende personagen die mit mijn voirs genadichsten heeren alhier quamen om wijn dair op te haelen'. AKH, SAH, 399 f. 89v.
} 
Silverware, money and wine gifts for the retinue and officers on the occasion of a princely entry cannot be viewed as simple courtesies. With a new prince the networks of officers in service of court and state often changed, especially in the higher echelons. For the subjects, these officers were more than the prince, the face of the Burgundian-Habsburg state. They were the ones with whom they had to deal and to negotiate on new privileges and new taxes. So it was important for the towns to establish a good relationship with the prince but also with his officers. The offering of hospitality, money and wine gifts could be the starting point of this relationship.

Concerning the gifts for the lower officials, Table 3, several differences can be noticed. They were bestowed not on individuals but on a group. The heralds, the trumpet players, the doorkeepers, the messengers, the archers and so on were all given 'drinking money'. They did not receive their own jug, or a lead token with which they could obtain their jug but money with which they had to acquire their own beverages. I suspect that the leader, formal or informal, of every group of officers received this money. It is interesting that some groups of officers were offered money in Mons but they refused to accept it, but the lackeys, the 'cuisiniers' and the 'sommeliers de la cave' did accept wine money in Bruges and Den Bosch. The reason for the refusal is not clear. Did they simply forget to collect the money or did they think that the sum offered was too small? We cannot be sure.

Bearers of information (messengers) and guards of the 'information portals' (doorkeepers) were crucial for any town in a society where one was dependent on people for access to information. Heralds and musicians could perform similar services and as 'sign bearers' they represented a direct link to the prince. ${ }^{60}$ That is why they could not only count on a gift for a specific service or performance but also on the occasion of an entry. A good relationship with these low-ranking officials meant direct access to the prince and his entourage.

\section{The citizens and the clergy}

As was stated above, the citizens had to offer their houses for the retinue of the prince. Moreover, they helped to decorate the town and participated in the plays and tableaux vivants performed along the itinerary of the prince. Finally, they witnessed the oath exchange by the prince and the political elite of the town and with their presence they affirmed the political support for the prince. Thus, as collaborators and spectators they were crucial for a successful entry. Did the prince, apart from his visit and promise to be a good ruler, value this and did he give something back to the audience?

In 1515 both in Middelburg and Den Bosch there is evidence that money was thrown into the audience directly after the oath ceremony. ${ }^{61}$ The distribution of money during banquets, weddings and other princely festivities seems to have become a tradition in the late middle ages. ${ }^{62}$ At least in 1549 Calvete de Estrella describes how in almost every town the kings of arms threw golden and silver coins from the stage on which the oath ceremony had taken place. The money

\footnotetext{
${ }^{60}$ Groebner, Liquid assets, 37-8, 142-3.

${ }^{61}$ Kroniek van Peter van Os, 338; Smit, Vorst en onderdaan, 342, 547.

${ }^{62}$ Malcolm Vale, The princely court. Medieval courts and culture in north-west Europe 1270-1380 (Oxford 2001), 238-9. See also the description of a banquet offered in 1520 by king Henry VIII of England: 'Au tiers service y eut largesse criée par les Roys d'armes et Herauts, ayans un grand pot d'or bien riche, et fut crié au nom dudit Roy d'Angleterre, disant: "Largesse de par tres-haut, tres-puissant, et tres-excellent prince Henry par la grâce de Dieu Roy d'Angleterre et Seigneur d'Irlande, largesse, largesse"; et là cria Montjoy (...)': Jean Starobinski, Largesse (Paris, 1994), 33 and the interpretation by Davis, The gift, 27 who stresses the redistribution of the money.
} 
Table 3

Selection of gifts from the towns to the retinue (low-ranking) of Charles V on the occasion of his inauguration in $1515^{1}$

\begin{tabular}{|c|c|c|c|c|c|c|c|}
\hline Function & Louvain & Den Bosch & Bruges & Mons & Leiden & Haarlem & Middelburg \\
\hline Heralds & $3 \mathrm{lb}$. & & $1 \mathrm{lb}$. & $4 \mathrm{lb} .4 \mathrm{~s}$. & 3 lb. 14 s. 8 d. & $\begin{array}{l}4 \times 0.5 \text { jug } \\
2 \mathrm{lb} .\end{array}$ & $15 \mathrm{lb}$. \\
\hline Trumpets & $8 \mathrm{lb}$. & 3 guilders & $1 \mathrm{lb}$. & $4 \mathrm{lb}$. & 5 lb. $12 \mathrm{~s}$. & $8 \times 0.5$ jug & 7 lb. $10 \mathrm{~s}$. \\
\hline Doorkeepers & $3 \mathrm{lb}$. & 4 guilders & $1 \mathrm{lb}$. & $3 \mathrm{lb}$. & 3 lb. 14 s. 8 d. & $2 \mathrm{lb}$ & $3 \mathrm{lb}$ \\
\hline Archers & $8 \mathrm{lb}$. & 3 guilders & $1 \mathrm{lb}$. & $3 \mathrm{lb}$. & $37 \times 0.5$ jug & $\begin{array}{l}80 \times 0.5 \text { jug } \\
2 \mathrm{lb} .10 \mathrm{~s} .\end{array}$ & $7 \mathrm{lb} .10 \mathrm{~s}$. \\
\hline Messengers & 2 lb. 2 s. & & & $3 \mathrm{lb}$. & & $1 \mathrm{lb}$ & \\
\hline Lackeys & $4 \mathrm{lb}$ & 5 guilders & $1 \mathrm{lb}$. & Refused & $3 \mathrm{lb}$ & 2 lb.10s. & $6 \mathrm{lb}$. \\
\hline Chapel & $8 \times 0.5$ jug & 1 guilder & & & 2 lb. $4 \mathrm{~s}$. & 29 jugs & \\
\hline Fouriers & $4 \mathrm{lb} .10 \mathrm{~s}$ & & $1 \mathrm{lb}$. & $2 \mathrm{lb} .10 \mathrm{~s}$. & $5 \mathrm{lb} .4 \mathrm{~s}$ & 2 lb.10s. & $3 \mathrm{lb}$. \\
\hline Kitchen & $1 \mathrm{lb}$ & & & Refused & 2 lb. 7 s. 4 d. & $8 \times 0.5$ jug & $1 \mathrm{lb}$. \\
\hline
\end{tabular}

${ }^{1}$ Sources: see footnote in Table 1.

was received by the public with 'a common and intense sentiment of joy', according to Calvete. $^{63}$

Although few people will have noted the material generosity of the prince, the symbolic impact should not be underestimated. The act of giving was more important than what was given; largesse was used to increase the prestige of the prince by showing his wealth and his ability to give. ${ }^{64}$ This virtue was even stressed by the coins themselves: in Ghent the coins bore the figure of prince Philip 'al natural' on the one side, whereas on the other side the royal coats of arms with the text: COLIT ARDUA VIRTUS. ${ }^{65}$ It was not only the material value that counted, the coins had a propagandistic purpose too. The lucky citizens who had got hold of a coin now had a representation of the new prince which could be shown to neighbours and friends.

Thus, the prince's generosity remained rather symbolic. Even the amounts of money spent on almsgiving were not significantly higher in years of joyous entries. ${ }^{66}$ Although the poor did not benefit from the prince's inauguration, this did not apply to the religious institutions. Normally, the prince attended mass in the principal church of the town before or after the oath ceremony. In the churches St Donatian in Bruges, St Vincent in Valenciennes and St Alban in Namur, it was a custom that the new prince donated a 'drap d'or' for the decoration of the church, although more and more this was replaced by a gift of money. ${ }^{67}$ With

\footnotetext{
${ }^{63}$ Calvete de Estrella, El felicissimo viaie, f. 88v (Louvain), f. 110r (Ghent), f. 122r (Bruges), f. 128r (Ypres), f. 148v (Lille), f. 160r (Tournai), f. 219v (Malines), f. 257r (Antwerp), f. 289r (Amsterdam).

${ }^{64}$ Sharon Kettering, 'Gift-giving and patronage in early modern France', French History, 2 (1988), 138; B. Buettner, 'Past presents: New Year's gifts at the Valois courts, ca. 1400', Art Bulletin, 83 (2001), 615-6.

${ }^{65}$ Calvete de Estrella, El felicissimo viaie, f. 110r.

${ }^{66}$ Mario Damen, 'Gift exchange at the court of Charles the Bold', in: In but not of the market: movable goods in late medieval and early modern urban society, ed. M. Boone and M. Howell (Brussels, 2006) in press.

${ }^{67}$ St Donatian: Comptes de l'argentier de Charles le Téméraire duc de Bourgogne 1: Année 1468, Anke Greve, Émilie Lebailly and Werner Paravicini eds. (Paris, 2001), no. 617: gift of a 'drap d'or' in April 1468 on the occasion of Charles the Bold's joyous entry into Bruges; ADN B $2159 \mathrm{f}$. 187v: gift of $13 \mathrm{lb}$. in March 1497 on the occasion of Philip the Fair's entry. In August 1498 Philip donated another 180 pounds for the purchase of a chasuble and two tunics decorated with his coats of arms: ADN B 2162 f. 203v. St John: Comptes de l'argentier de Charles le Téméraire, no. 851: gift of a drap d'or in June 1468 on the occasion of Charles the Bold's joyous entry into Valenciennes. St Alban: ADN B $2151 \mathrm{f}$. 240r: gift of 30 pounds for decoration in May 1495 on the occasion of Philip the Fair's entry into Namur. See as an example the chasuble given by Margaret of York to the church of St Peter and St Paul of Malines: Women of distinction. Margaret of York and Margaret of Austria, ed. D. Eichberger (Louvain, 2005), 72.
} 
this gift the duke established also a bond with the urban clergy, who were at the same time more often than not important fief holders. In St Waudru of Mons, for example, the gift ceremony formed an important part of the feudal homage between the duke and the secular abbot of the chapter. When Philip the Good in 1433 refused to give a gold cloth to the church, the chapter even claimed compensation from the Chambre des Comptes. ${ }^{68}$

Although donations of money, cloth and other building related gifts were not restricted to years of joyous entries, a significant part of the donations can be connected to these festivities. It is noteworthy that most gifts for the installation of glass windows were given during or shortly after the prince had visited the town. Again these were not always voluntary gifts. The prince could not possibly know which church needed new windows. Therefore, convents and churches had to lobby actively for donations to finance windows when new churches were built or old churches rebuilt. A direct approach to the prince or one of his representatives was an effective method to obtain money, or at least to remind the prince of his duty to protect the Church. ${ }^{69}$ At the same time for the prince a donation of a glass window was a relatively cheap contribution to memorial and devotional practices. Moreover, in these windows the dynasty, whose members were more and more absent from the Low Countries, could represent itself continuously to churchgoers, who moreover were stimulated to pray for the salvation of their souls.

An example can illustrate this. In November 1494 Philip the Fair and Maximilian financed three glass windows to be placed in the choir of the church of St Peter in Reimerswaal where Philip was inaugurated by the Estates of Zeeland. ${ }^{70}$ In the stained-glass windows were depicted the Crucifixion in the central window, Maximilian and his deceased wife Mary of Burgundy on one side and Philip the Fair and his sister Margaret on the other side. The glass in commemoration of Mary of Burgundy served to stimulate the churchgoers to pray for the salvation of her soul. In this respect, the choice for the Crucifixion was obvious. It was one of the most popular representations on memorial glasses because it showed how Christ sacrificed himself for mankind, liberating them from original sin and making eternal life possible. ${ }^{71}$

Next to the devotional aspect, the windows carried out a clear political statement as they were the bill boards of the middle ages. Not surprisingly the church was one of the few parochial churches of Zeeland which Philip as count enjoyed the right of presentation to its ecclesiastical benefices. ${ }^{72}$ Moreover, the Burgundian and Habsburg princes visited the town, next to the Brabantine border, more and more as the first (and sometimes only) place for their inauguration in Zeeland or for seeking a subsidy. The new young prince, at that time he was only 16 years old, was presented to the public not alone but in the presence of his father Maximilian, king of the Romans, and his sister. The churchgoers would constantly be reminded of the Habsburg dynasty in general and the new ruler in particular.

\footnotetext{
${ }^{68}$ Hurlbut, 'The duke's first entry', 169-70.

${ }^{69}$ Mario Damen, 'Vorstelijke vensters. Glasraamschenkingen als instrument van devotie, memorie en representatie (1419-1519)', Jaarboek voor middeleeuwse geschiedenis, 8 (2005), 140-200.

${ }^{70}$ Gift: ADN B 2148 f. 161r. Inauguration: Smit, Vorst en onderdaan, 239.

${ }^{71}$ Truus van Bueren and W.C.M. Wüstefeld, Leven na de dood. Gedenken in de late middeleeuwen (Turnhout, 1999), 12-14.

72 A.G. Jongkees, Staat en kerk in Holland en Zeeland onder de Bourgondische hertogen (Groningen and Batavia, 1942), 270-2.
} 


\section{Conclusion}

The entry of a new prince into the towns of the Low Countries was characterised by both a symbolic and a material gift exchange. In this article not much has been said about the symbolic exchange (that of the oaths) and emphasis had been on the material part. The town was concerned for its honour and reputation and offered the prince hospitality, public space and gifts in exchange for his visit. There were no fixed prescriptions to what was to be given. The gifts were not determined by tradition, even it was often claimed that they were. Furthermore, the data presented show that not all gifts were given spontaneously, but were the result of a negotiating process between the town and the prince's officials on the one hand and between the different towns of a principality on the other. ${ }^{73}$ During the months of negotiations that preceded the joyous entry, the prince's officers and the town's delegates deliberated on new privileges in exchange for new subsidies. The gifts can be considered as a personalised item in a bigger process of exchange and as a confirmation of the outcome of political negotiations which could differ with time and place.

The differing circumstances surrounding these negotiations are highlighted in the case of the entry of King Louis XI into Tournai in 1464. In a way the town was special because it formed a French enclave in Burgundian territory. Therefore it is understandable that the town put in a great effort to give a warm welcome to the royal dynasty. Whereas a new prince normally took over part of the retinue and administrative apparatus of his predecessor, in this case the town had to establish relationships with a completely new court and state apparatus. The handing over of presents during the contact-intensive period of a princely entry was an effective method for this. Gifts of silverware and horses show that the towns adopted the noble and princely gift culture. Moreover, the entry gift trickled down to lower levels in the official hierarchy.

Although the symbolic gift exchange (the oath ceremony) can be characterised as balanced reciprocity, the material gift exchange is more an example of generalised reciprocity: the counter gift is not specified and it is not clear what or when it is going to come. ${ }^{74}$ What could the urban political elite expect from the new prince, apart from his oath of loyalty? In any case the treatment of the town's representatives when they visited the prince was far from hospitable. Normally, they were not hosted in the prince's residence - which did not even have enough space to host his own servants - but had to pay for their lodging in a hostel. Sometimes, the duke gave presents to specific members of the urban political elite, for example pensionaries or burgomasters for 'services performed', or on the occasion of a baptism or a marriage. ${ }^{75}$ But of course we should look beyond this system of clientage and seek for specific arrangements

\footnotetext{
73 Schenk, Zeremoniell und Politik, 393.

${ }^{74}$ Marshall Sahlins, 'On the sociology of primitive exchange', in: The gift: an interdisciplinary perspective, ed. Aafke Komter (Amsterdam, 1996), 34-5.

75 In July 1468 for example, Charles the Bold rewarded a burgomaster of Enkhuizen in North Holland, with a silken robe, valued at 20 pounds, for services performed. Jean Breydel, burgomaster of Bruges, received in December 1468 silverware valued at more than 50 pounds when he had his son baptized and named after the duke. Comptes de l'argentier de Charles le Téméraire, nos. 1028, 2048. The Burgundian dukes had a strong preference for university trained pensionaries when recruiting new officials: Walter Prevenier, 'Ambtenaren in stad en land in de Nederlanden. Socioprofessionele evoluties (veertiende tot zestiende eeuw)', Bijdragen en mdedelingen betreffende de geschiedenis der Nederlanden, 87 (1972), 49; M. Boone, 'Les juristes et la construction de l'État bourguignon aux Pays-Bas. Etat de la question, pistes de recherches', in: Les Pays-Bas bourguignons. Histoire et institutions. Mélanges André Uyttebrouck, ed. J.-M. Duvosquel, J. Nazet and A. Vanrie (Brussels, 1996), 111.
} 
and privileges conceded to the town. In this sense the gifts given during a princely entry were the start of a series of exchanges between the prince and his subjects, the outcome of which was undetermined.

Mario Damen studied history at the universities of Leiden (the Netherlands) and Santiago de Compostela (Spain). In 2000 he obtained his PhD (cum laude) at the Vrije Universiteit Amsterdam. His dissertation was a prosopographical study on the officers of the Council and Chambre des comptes of Holland and Zeeland in the fifteenth century. From 2000 onwards he has worked as a lecturer in medieval history at the University of Leiden. His main research has been the functions of gift-exchange in the late medieval Low Countries, and currently he is working on the nobility of Brabant as part of the major research project 'Burgundian nobility'. 